\title{
Callus Induction and Elicitation of Total Phenolics in Callus Cell Suspension Culture of Celastrus paniculatus - willd, an Endangered Medicinal Plant in India
}

\author{
Anusha T S, Joseph M V and Elyas K K \\ Department of Biotechnology, University of Calicut, Thenjipalam, Kerala, INDIA.
}

\begin{abstract}
Celastrus paniculatus - Willd belonging to the family Celastraceae is a vulnerable medicinal plant in India. It has been employed as a stimulant, nervine tonic, rejuvenant, sedative, tranquilizer and diuretic. It is also used in the treatment of leprosy, leucoderma, rheumatism, gout, paralysis and asthma. Because of its high pharmaceutical application, this plant species were over exploited and now considered under threatened species. So the highlight of the present investigation is the induction of callus by using different concentration of various phytohormones such as 2, 4-D (0.5 - 3.0 $\mathrm{mg} / \mathrm{l})$ and NAA $(0.5-2.5 \mathrm{mg} / \mathrm{l})$. In order to ensure the presence of the bioactive compounds preliminary phytochemical screening of the various extracts of callus were performed. Finally elicitation of total phenolics were done in callus cell suspension cultures by using elicitors such as jasmonic
\end{abstract}

acid, salicylic acid and copper sulphate. Among the applied elicitors jasmonic acid showed superiority. To our knowledge, this is the first report of the elicitation of secondary metabolites especially total phenolics from callus cell suspension cultures of Celastrus Paniculatus.

Keywords: Celastrus paniculatus, Callogenesis, Bioactive constituents, Elicitors, Total phenolics.

Corresponding author: Dr. K K Elyas, Professor, Department of Biotechnology, University of Calicut, Thenjipalam, Kerala, INDIA.

Email: anushatsbiotech@gmail.com

DOI : 10.5530/pj.2016.5.10

\section{INTRODUCTION}

Celastrus paniculatus Willd belongs to family Celastraceae is a large, woody, climbing shrub, distributed almost all over India is known for its ability to improve memory. ${ }^{1}$ Botanical name: Celastrus paniculatus Willd Family: Celastraceae Synonym: Celastrus dependens Vernacular names: Hindi - Malkangani; English - Staff tree; Kannada - Kariganne; Tamil - Valuluvai; Telugu -Malkangani. Botanical description: Celastrus paniculatus Willd. is a climbing or scrambling shrub, with erect branches; the young shoots and branches are pendulous. Leaves - glabrous, broadly ovate or obovate, a cuminate or acute. Flowers - unisexual, yellowishgreen, borne in terminal, pendulous panicles (flowering throughout the year). It has a fast gaining importance in the primary healthcare systems as well as in herbal drug formulations. ${ }^{2}$ This plant has much more importance in Indian system of medicines such as Ayurveda, Folk, Siddha, and Unani to cure many diseases such as leprosy, leucoderma, skin diseases, paralysis, depression, arthritis, asthma and cancer. ${ }^{3}$ Many pharmacological studies proved that the antioxidant,anti-inflammatory and anticancerous activity of this plant. ${ }^{4-6}$ The phytochemical analysis revealed the presence of alkaloid such as celastrine, paniculatin, celapagine and celapanine ${ }^{7}$ which possess anticancerous activity. The objective of the present investigation is to enhance the production of secondary metabolites especially phenolics in callus cell suspension culture. The different elicitors such as Jasmonic acid, Salicylic acid and copper sulphate were used for the present study. The elicitors were added with varing concentrations $(25,50$, 100 and $250 \mu \mathrm{M}$ ) and incubated for 24,48 and 72 hrs to check the enhanced production of total phenolics.

\section{MATERIALS AND METHODS}

\section{Plant material}

Approximately 10-year-old plant of Celastrus paniculatus maintained in the Botanical garden, University of Calicut were used as explants source. The collected plant material were identified and authenticated by Dr, A K Pradeep , Assistant professor, Department of Botany, University of Ca- licut. University of Calicut was used as explant source. Juvenile shoots obtained from freshly emerged sprouts were collected. The nodal segments as well as midrib $(3-5 \mathrm{~cm})$ were used as explants.

\section{Surface sterilization}

Endophytic microflora is a major cause of contamination; hence in order to prevent the chance of contamination surface sterilization were done. Explants were first washed under running tap water for about $30 \mathrm{~min}$ followed by treatment with $2.5 \% \mathrm{NaOCl}$ for $10 \mathrm{~min}$ and subsequently washed with sterile distilled water for 4-5 times. The explants were further surface sterilized with $0.1 \% \mathrm{HgCl}_{2}$ for $10 \mathrm{~min}$. Explants were finally rinsed (5-6 times) with sterile double-distilled water to remove any traces of the surfactants.

\section{Nutrient media and culture conditions}

MS medium ${ }^{8}$ supplemented with 3.0\% sucrose and 0.8\% Agar-agar (Hi-Media, India). The $\mathrm{pH}$ of the medium was adjusted to 5.8 and then autoclaved for $15 \mathrm{~min}$ at $121^{\circ} \mathrm{C}$. The cultures were maintained at $24^{\circ} \mathrm{C}$ $\pm 2^{\circ} \mathrm{C}$ under 12 -h photoperiod (provided by fluorescent lamb). Each treatment was carried out with 12 culture bottles with single explant per bottle and each experiment repeated as twice. The response in various media was expressed in terms of mean number of callus fresh weight. Callus morphology were also recorded.

\section{Callogenesis}

The leaf explants of Celastrus paniculatus were used for callus induction. The callus was induced in MS medium fortified with various concentrations of 2,4-D (0.5 - $3.0 \mathrm{mg} / \mathrm{l})$ alone and a combination with optimum concentration of 2,4-D $(1.5 \mathrm{mg} / \mathrm{l})$ with varying concentrations of NAA (0.5 - $2.5 \mathrm{mg} / \mathrm{l})$.The percentage of callus induction was recorded. The callus was observed every 10 days and was subcultured at an regular interval of 15-20 days. The culture bottle was maintained under aseptic conditions. 
All the experiments were repeated twice with a minimum of 12 replicates. Each bottle contains single explant and all the results were expressed as the mean \pm SD for all experiments.

\section{Preliminary phytochemical screening}

The powdered samples of callus extract of Celastrus paniculatus were screened for phytochemical constituents using standard procedures (Harborne 1998).

\section{Extract from callus}

The dried callus were ground into a course powder, 10gram each of the powder was mixed with $40 \mathrm{ml}$ of chloroform, petroleum ether, ethyl acetate and methanol in $250 \mathrm{ml}$ of conical flask and was kept at room temperature for $24 \mathrm{hrs}$. The suspension was filtered through Whatman's filter paper and collected in large Petri plates. These were allowed to dry completely in water bath set at $40 \pm 0.2^{\circ} \mathrm{C}$ for $30 \mathrm{~min}$. Dried extracts were scraped out by using scalpels and was collected in pre weighed vials separately. Extracted powders were made available to use as per requirements by re suspended in the above solvents used for various analysis.

\section{Cell suspension culture}

The six week old callus from in vitro culture was transferred into liquid MS medium supplemented with the same hormonal combination without agar. The cell suspension culture was grown for 25 days with $110 \mathrm{rpm}$ in shaker at room temperature.

\section{Elicitors}

Various elicitors such as Jasmonic acid, Salicylic acid and copper sulphate were used for the elicitation of secondary metabolites in cell suspension culture. The various concentrations of the elicitors such as $25,50,100$ and $250 \mu \mathrm{M}$ were added on the $25^{\text {th }}$ day of callus cell suspension culture. These cultures were incubated at $25 \pm 2^{\circ} \mathrm{C}$ in gyratory shaker at $110 \mathrm{rpm}$ under dark condition. The effects of different concentrations of the elicitors were recorded for 24,48 and $72 \mathrm{hrs}$ of treatment duration and all the experiments were repeated thrice.

\section{Determination of total phenolic content}

Total phenolic content of the callus cell suspension culture of Celastrus paniculatus was determined by Folin- Ciocalteau method using gallic acid as standard. ${ }^{9}$ The total phenolic content of the extracts were expressed as gallic acid equivalents.

\section{RESULTS AND DISCUSSION}

\section{Callus induction}

MS medium modified with various levels of 2,4-D (0.5-3.0 mg/l) alone and a combination with NAA(0.5-2.5 mg/l) resulted callus formation from leaf explants. The callus response was slow at the initial stages but the callus exhibited good growth within 25 days and covered the entire explants. MS medium with $1.5 \mathrm{mg} / \mathrm{l}$ of 2,4 -D was the best concentration for the callogenesis and showed $88 \%$ callus response (Table 1). In the leaf explants, the callus developed from the adaxial as well as abaxial surface. The callus developed on the optimal concentration of 2, 4-D was friable, shiny and cream coloured. The combination of optimum concentration of 2,4-D with varying concentrations of NAA favoured the callus development. The same combination exhibited the organogenic nature of callus (Figure 1).

\section{Qualitative phytochemical screening}

The preliminary phytochemical screening of different bioactive compouds was found to vary depending on the polarity of the solvents. The screening was performed by using standard procedures and is summarized in the Table 2.

In the present investigation, the qualitative test for most of the extracts showed significant indication about the presence of the metabolites. In comparison to the other extracts, the methanolic extract of Celastrus paniculatus showed majority of phytoconstituents such as phenols, glycosides, aldehyde, alkaloids, tannins, terpenoid, flavanoids, and saponinns. The ethyl acetate extract showed the presence of glycosides, phlobotannins, alkaloids, tannins, steroids and flavanoids. The petroleum ether extract showed positive results to only few bioactive compounds, such as phlobotannins, glycosides and terpenoids. The chloroform extract showed the presence of compounds such as reducing sugar, flavanoids, steroids, glycosides and aldehyde. The similar results were reported by ${ }^{10}$ using different extracts of Celastrus paniculatus seeds.

\section{Effect of Jasmonic acid on total phenolics}

Jasmonic acid (JA) is a naturally occurring growth regulator found in higher plants. Several physiological roles have been described for this compound (or a related compound, methyl jasmonate) during plant development and in response to biotic and abiotic stress. The results obtained in jasmonic acid treated cell suspension culture samples with respect to total phenolics are shown in Table 3.

After $24 \mathrm{hrs}$ of treatment the total phenolics were maximum in $250 \mu \mathrm{M}$ of jasmonic acid was $43.18 \pm 0.42 \mu \mathrm{g} / \mathrm{g}$, which is higher than control. In 48 hours of treatment, the maximum response in terms of total phenolics was obtained in the same concentration, $104.51 \pm 0.33 \mu \mathrm{g} / \mathrm{g}$. Whereas in $72 \mathrm{hrs}$ of treatment duration $50 \mu \mathrm{M}$ of jasmonic acid was observed maximum response of total phenolics was $106.82 \pm 0.11 \mu \mathrm{g} / \mathrm{g}$. Many workers reported that jasmonic acid has been used to modulate the production of various secondary metabolites in plant tissue culture techniques ${ }^{11-15}$ reported that the enhanced secondary metabolite production is usually associated with rapid, transient increase in the activity of key enzymes of the phenylpropanoid pathway such as phenylalanine ammonia lyase and chalcone isomerase.

\section{Effect of salicylic acid (SA) on total phenolics}

Salicylic acid (SA) is a hormone-like substance that plays an important role in the regulation of plant growth and development ${ }^{16-18}$ The results obtained in salicylic acid treated cell suspension culture samples with respect to total phenolics are shown in Table 4.

After 24 hrs of treatment duration, the total phenolics were maximum in $100 \mu \mathrm{M}$ of salicylic acid with a yield of $56.24 \pm 1.63 \mu \mathrm{g} / \mathrm{g}$. Whereas in the case of 48 and $72 \mathrm{hrs}$ of treatment duration the optimum concentration inducing high increase in total phenolic concentration was $250 \mu \mathrm{M}$ which was $92.23 \pm 1.55 \mu \mathrm{g} / \mathrm{g}$ and $99.23 \pm 0.27 \mu \mathrm{g} / \mathrm{g}$ respectively.

SA has attained more attention because of its involvement in plant defense mechanisms, such as establishment of systemic acquired resistance (SAR), ${ }^{19}$ induction of pathogenesis related (PR) proteins ${ }^{20}$ as well as hypersensitive response. ${ }^{21}$ The protective effect of SA against abiotic stress factors such as toxic metals, ${ }^{22}$ heat stress, ${ }^{23}$ low temperature ${ }^{24,25}$ and oxidative damage ${ }^{22,26}$ has been demonstrated. SA has been reported to induce salinity tolerance in tomato, ${ }^{27}$ maize, ${ }^{28}$ carrot $^{29}$ and wheat. ${ }^{30}$ It has also been used to enhance in vitro regeneration in several plant species. ${ }^{31-33}$

\section{Effect of Copper sulphate on total phenolics}

The metals like copper, cobalt, iron, manganese and zinc are essential for plant life but are required in a very small or trace amounts ${ }^{34,35}$ Among them, copper salts such as copper sulphate and copper chloride were successfully used as abiotic elicitors in number of plant cell culture. ${ }^{36}$ 

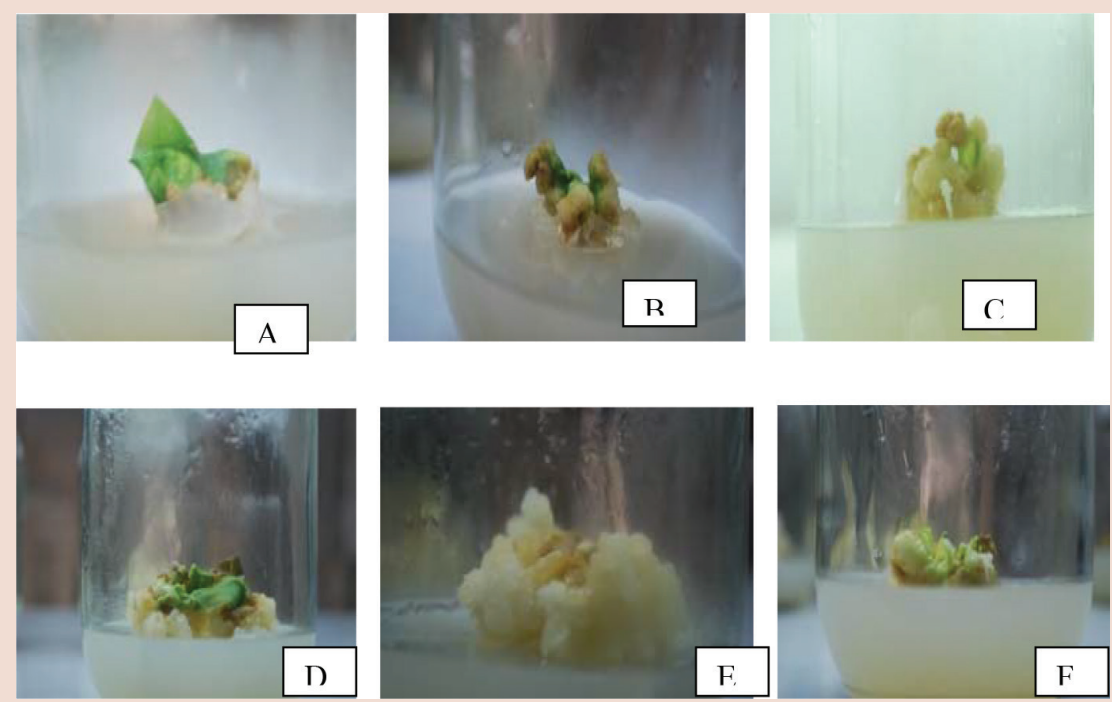

Figure 1: The various developmental stages of callus proliferation from leaf explants celastrus paniculatus A-E) Callus initiation from leaf explants on MS medium supplemented with different concentrations of 2,4-D (0.5-2.5 mg/l) alone and a combination of optimum concentration of 2,4-D and varying concentrations of NAA(0.5 - $2.5 \mathrm{mg} / \mathrm{l})$. Creamy, friable callus were obtained. F) Organogenic callus and initiation of shoot formation on MS medium supplemented with $1.5 \mathrm{mg} / \mathrm{l}$ of 2,4-D with $1.0 \mathrm{mg} / \mathrm{l}$ of NAA.

Table 1: Effect of 2, 4-D and NAA for callus induction from leaf explants of Celastrus paniculatus

\begin{tabular}{ccc}
$\begin{array}{c}\text { Hormone conc. } \\
\text { (mg/l) }\end{array}$ & $\begin{array}{c}\text { Callus } \\
\text { Response } \\
(\%)\end{array}$ & Callus morphology \\
\hline $2,4-\mathrm{D}$ & & \\
0.5 & $32.40 \pm 2.1$ & Whitish green \\
1.0 & $58.20 \pm 1.40$ & Whitish green, hard \\
1.5 & $88.10 \pm 2.38$ & Cream, friable \\
2.0 & $70.34 \pm 1.93$ & Cream,white, friable \\
2.5 & $64.40 \pm 1.23$ & Pale green, friable \\
$2,4-\mathrm{D}+\mathrm{NAA}$ & & \\
$1.5+0.5$ & $60.10 \pm 1.20$ & $\begin{array}{c}\text { Pale green, hard } \\
1.5+1.0\end{array}$ \\
$1.5+1.5$ & $86.42 \pm 2.03$ & Cream,friable. \\
$1.5+2.0$ & $79.23 \pm 1.62$ & Chiny cream,friable \\
$1.5+2.5$ & $72.43 \pm 0.38$ & Cream, hard \\
& & \\
\hline
\end{tabular}

The results obtained in copper sulphate treated cell suspension culture samples with respect to total phenolics are shown in Table 5.

After 24 hrs of treatment duration, the total phenolic concentration was maximum in $250 \mu \mathrm{M} \mathrm{CuSO} 4$ treated sample, which was $96.30 \pm 1.22$ $\mu \mathrm{g} / \mathrm{g}$. In the 48 hours treatment, $100 \mu \mathrm{M} \mathrm{CuSO} 4$ was found to be most effective with respect to total phenolic production with yielded 88.83 $\pm 1.12 \mu \mathrm{g} / \mathrm{g}$. Whereas in the $72 \mathrm{hrs}$ treated sample, $250 \mu \mathrm{M}$ CuSO 4 was observed to be optimal concentration and yielded $67.38 \pm 1.77 \mu \mathrm{g} / \mathrm{g}$ of total phenolics.

Copper performs very important physiological and biochemical processes include photosynthesis, respiration, conversion of nitrogen compounds, transport of carbohydrates and also it is a constituent of the protein component of several enzymes in plants, mainly those participating in electron flow, catalyzing redox reactions in mitochondria, chloroplasts, cell wall and cytoplasm of plant cells. ${ }^{37,38}$ reported that the addition of $40 \mu \mathrm{M} \mathrm{CuSO} 4$ to the medium significantly increased the embryoids production from wheat anther cultures. ${ }^{39}$ studied the effect of different
Table 2: Preliminary phytochemical screening of bioactive compounds present in different extracts of Celastrus paniculatus

\begin{tabular}{ccccc}
\hline $\begin{array}{c}\text { Phytochemical } \\
\text { constituents }\end{array}$ & $\begin{array}{c}\text { Petroleum } \\
\text { ether extract }\end{array}$ & $\begin{array}{c}\text { Chloroform } \\
\text { Extract }\end{array}$ & $\begin{array}{c}\text { Methanol } \\
\text { extract }\end{array}$ & $\begin{array}{c}\text { Ethyl } \\
\text { acetate } \\
\text { extract }\end{array}$ \\
\hline $\begin{array}{c}\text { Reducing sugars } \\
\text { Anthraquinones }\end{array}$ & - & + & - & - \\
Saponins & - & - & - & - \\
Flavanoids & - & + & + & + \\
Steroids & - & + & + & - \\
Terpenoids & + & + & - & + \\
Tannins & - & - & + & + \\
Alkaloids & - & - & + & + \\
Aldehyde & + & + & + & + \\
Phenols & - & - & + & - \\
Glycosides & + & + & + & + \\
Phlobotannins & + & - & - & + \\
\hline
\end{tabular}

concentrations of CuSO4 on callus culture of two cultivars of barley and found that medium containing $50 \mu \mathrm{M}$ copper regenerated significantly more plants. Total and phenol content increased at high concentration of $\mathrm{Cu}$ and $\mathrm{Zn} .{ }^{40}$

\section{CONCLUSION}

From the present investigation it was concluded that MS medium modified with various levels of 2,4-D (0.5-3.0 mg/l) alone and a combination with NAA (0.5-2.5 mg/l) resulted callus formation from leaf explants. Phytochemical screening of the different callus extracts of Celastrus paniculatus contained many bioactive constituents which includes reducing sugars, anthraquinones, phenols, flavanoids, alkaloids, steroids, terpenoids, phlobotannins, aldehydes/ketones, glycosides, saponins and tannins. The presence of these bioactive constituents suggests potential source for useful drugs, and enhancers of the health status. These findings of phytochemicals were good enough to reflect its importance. The comparative enhancement in phenolic content by elicitors was the point of interest in 
Table 3: Effect of Jasmonic acid on phenolic production in celastrus paniculatus

\begin{tabular}{ccc}
\hline $\begin{array}{c}\text { Treatment } \\
\text { Duration }\end{array}$ & $\begin{array}{c}\text { Concentration of } \\
\text { Elicitor }\end{array}$ & $\begin{array}{c}\text { Total phenolics } \\
\text { in } \mu \mathrm{g} / \mathrm{g}\end{array}$ \\
\hline \multirow{3}{*}{$24 \mathrm{hrs}$} & Control & $3.54 \pm 0.25$ \\
& $50 \mu \mathrm{M}$ & $9.44 \pm 0.27$ \\
& $100 \mu \mathrm{M}$ & $34.61 \pm 0.61$ \\
$48 \mathrm{hrs}$ & $250 \mu \mathrm{M}$ & $39.25 \pm 0.46$ \\
& Control & $43.18 \pm 0.42$ \\
& $25 \mu \mathrm{M}$ & $22.45 \pm 0.63$ \\
& $50 \mu \mathrm{M}$ & $9.49 \pm 0.37$ \\
& $100 \mu \mathrm{M}$ & $42.78 \pm 0.47$ \\
& $250 \mu \mathrm{M}$ & $69.31 \pm 0.31$ \\
& $\mathrm{Control}$ & $104.51 \pm 0.33$ \\
& $25 \mu \mathrm{M}$ & $9.30 \pm 0.28$ \\
& $50 \mu \mathrm{M}$ & $84.20 \pm 0.38$ \\
& $100 \mu \mathrm{M}$ & $106.82 \pm 0.11$ \\
& $250 \mu \mathrm{M}$ & $32.30 \pm 0.62$ \\
& & $30.40 \pm 0.28$ \\
\hline
\end{tabular}

Table 4: Effect of Salicylic acid on phenolic production in celastrus paniculatus

\begin{tabular}{ccc}
\hline $\begin{array}{c}\text { Treatment } \\
\text { Duration }\end{array}$ & Concentration of Elicitor & $\begin{array}{c}\text { Total phenolics } \\
\text { in } \mu \mathrm{g} / \mathrm{g}\end{array}$ \\
\hline \multirow{3}{*}{$24 \mathrm{hrs}$} & Control & $5.23 \pm 0.27$ \\
& $25 \mu \mathrm{M}$ & $7.39 \pm 1.24$ \\
$50 \mu \mathrm{M}$ & $24.67 \pm 1.52$ \\
& $100 \mu \mathrm{M}$ & $56.24 \pm 1.63$ \\
& $250 \mu \mathrm{M}$ & $9.24 \pm 1.55$ \\
& Control & $7.22 \pm 1.59$ \\
$48 \mathrm{hrs}$ & $25 \mu \mathrm{M}$ & $5.38 \pm 1.44$ \\
& $50 \mu \mathrm{M}$ & $22.53 \pm 1.63$ \\
& $100 \mu \mathrm{M}$ & $43.62 \pm 1.54$ \\
$72 \mathrm{hrs}$ & $250 \mu \mathrm{M}$ & $92.23 \pm 1.55$ \\
& Control & $6.26 \pm 1.73$ \\
& $25 \mu \mathrm{M}$ & $7.22 \pm 1.39$ \\
& $50 \mu \mathrm{M}$ & $23.56 \pm 1.83$ \\
& $100 \mu \mathrm{M}$ & $49.62 \pm 1.30$ \\
& $250 \mu \mathrm{M}$ & $99.23 \pm 0.27$ \\
\hline
\end{tabular}

the present investigation. The obtained result revealed that jasmonic acid is the most effective in eliciting in total phenolic production of callus cell suspension cultures of Celastrus paniculatus.

\section{ABBREVIATIONS USED}

12,4-D: 2,4 Deoxyribonucleic acid; NAA: Naphthalene acetic acid; $\mathrm{CuSO}_{4}$ : Copper sulphat; $\mathrm{HgCl}_{2}$ : Mercury chloride; $\mathbf{N a O C l}$ : Sodium hypochlorite.

\section{REFERENCES}

1. Nadkarani AK. Indian Materia Medica. Edn 3, Vol 1, Popular Prakashan, Bombay, 1976.
Table 5: Effect of Copper sulphate on phenolic production in celastrus paniculatus

\begin{tabular}{ccc}
\hline $\begin{array}{c}\text { Treatment } \\
\text { Duration }\end{array}$ & $\begin{array}{c}\text { Concentration of } \\
\text { Elicitor }\end{array}$ & $\begin{array}{c}\text { Total phenolics } \\
\text { in } \mu \mathrm{g} / \mathrm{g}\end{array}$ \\
\hline \multirow{3}{*}{$24 \mathrm{hrs}$} & Control & $6.77 \pm 1.43$ \\
& $25 \mu \mathrm{M}$ & $6.54 \pm 1.40$ \\
& $50 \mu \mathrm{M}$ & $38.72 \pm 1.26$ \\
& $100 \mu \mathrm{M}$ & $40.20 \pm 1.26$ \\
& $250 \mu \mathrm{M}$ & $96.30 \pm 1.22$ \\
& Control & $8.30 \pm 1.34$ \\
& $25 \mu \mathrm{M}$ & $28.83 \pm 1.25$ \\
& $50 \mu \mathrm{M}$ & $49.20 \pm 1.59$ \\
& $100 \mu \mathrm{M}$ & $88.83 \pm 1.12$ \\
& $250 \mu \mathrm{M}$ & $38.26 \pm 1.30$ \\
& Control & $5.30 \pm 1.52$ \\
& $25 \mu \mathrm{M}$ & $4.21 \pm 1.39$ \\
& $50 \mu \mathrm{M}$ & $6.92 \pm 1.27$ \\
& $100 \mu \mathrm{M}$ & $33.29 \pm 1.53$ \\
& $250 \mu \mathrm{M}$ & $67.38 \pm 1.77$ \\
\hline
\end{tabular}

2. Neha Arora Shashi panday - Rai. GC-MS analysis of the essential oil of Celastrus paniculatus Willd.seeds and antioxidant, anti-inflammatory study of its various solvent extracts. Int J Pharm Bio Sci. 2012;3(3):290-303.

3. Sharma PC, Yelne MB, Dennis TJ. Database on Medicinal Plants used in Ayurveda Central Council for Research in Ayurveda and Sidda. Janakpori, New Delhi. 2001;1(152):2

4. Martin G, Geetha SP, Raja SS, Raghu AV, Balachandran I,Ravindran PN. An efficient micropropagation system for Celastrus paniculatus Willd: a vulnerable medicinal plant. Journal of Forest Research. 2006;11(6):461-5.

5. Lal D, Singh N. Mass multiplication of Celastrus paniculatus Willd-an important medicinal plant under in vitro conditions using nodal segments. Journal of American Science. 2010;6(7):55-61.

6. Warrier PK, Nambiar VPK, and Ramankutty C. 1995. Indian Medicinal Plants. Orient Longman Ltd., Madras, Vol1-5.

7. CSIR. Wealth India - raw material, Council For Scientific and Industrial Research (CSIR), New Delhi. 1992;3:412-3.

8. Murashige T, Skoog F. A revised medium for rapid growth and bioassays with tobacco tissue culture. Physiol. Plant. 1962;15:473-97.

9. Gupta S, Prakash J. Studies on Indian green leafy vegetables for their antioxidant activity. Plant Food Hum Nutr. 2009;64(1):39-45.

10. Venkataramaiah and Wudayagiri Rajendra. Phytochemical Screening of Bioactive Compounds Present in the Seed of Celastrus paniculatus: Role in Traditional Medicine. Indo American Journal of Pharmaceutical Research. 2011;6:9014-11.

11. Lalit Srivastava M. 2002. Plant Growth And Development. Hormones and Environment. Academic Press, California, USA. Pp; 217-520.

12. Gundlach $\mathrm{H}$, Muller MJ, Kutchan MJ, Zenk MH. JA is a signal transducer elicitor induced plant cell cultures. Proceedings of the National Academy of Sciences USA. 1992;89(6):2389-93

13. George EF, Hall MA, Klerk GD. Plant propagation by tissue culture. Springer Ltd, Netherland. 2008;1(3-9):55-9.

14. Nojiri $H$, Sugimori $M$, Yamane $H$, Nishimura $Y$, Yamada $A$, Shibuya $N$, Kodama $O$ Murofushi N, Omori T. Involvement of jasmonic acid in elicitor-induced phytoalexin production in suspension-cultured rice cells. Plant Physiology. 1996; 110(2):387-92

15. Dixon R, Chen F, Guo D, Parvathi K. The biosynthesis of monolignols: a "metabolic grid", or independent pathways to guaiacyl and syringyl units Phytochemistry. 2001;57(7):1069-84

16. Raskin I. Role of salicylic acid in plants. Ann Rev Plant Physiol Mol Biol. 1992;43(1):439-63.

17. Kang S, Kim HL, Le H, Choi JY, Heu H, Oh CJ. Over expression of Arabidopsis of a plasma membrane-targeting glutamate receptor from small radish increases glutamate-mediated $\mathrm{Ca}^{+2}$ influx and delays fungal infection. Mol. Cells. 2006;21(3):418-27.

18. Taguchi G, Yazawa T, Hayashida N and Okazaki M. Molecular cloning and heterologous expression of novel glucosyltransferases from tobacco cultured cells that have broad substrate specificity and are induced by salicylic acid and auxin. Eur J Biochem. 2001;268(14):4086-94. 
19. Metraux JP, Signer H, Ryals J, Ward E, Wyss-Benz M, Gaudin J, Raschdorf K, Schmid E, Blum W, Inverardi B. Increase in salicylic acid at the onset of systemic acquired resistance in cucumber. Science. 1990;250:1004-6.

20. Malamy J, Carr JP, Klessig DF, Raskin I. Salicylic acid: A likely endogenous signal in the resistance response of tobacco to viral infection. Sci. 1990; 250(4983):1001-4.

21. Horvath E, Szalai G, Janda T. Induction of abiotic stress tolerance by salicylic acid signaling. J Plant Growth Regul. 2007;26(3):290-300.

22. Strobel N, and Kuc J. Chemical and biological inducers of systemic resistance to pathogens protect cucumber and tobacco plants from damage caused by Paraquat and cupric chloride. Phytopathology. 1995;85:1306-10

23. Dat JF, Foyer $\mathrm{CH}$, Scott IM. Changes in salicylic acid and antioxidants during induced thermotolerance in mustard seedlings. Plant Physiol. 1998;118(4):1455-61.

24. Janda T, Szalai G, Tari I, Páldi E. Hydroponic treatment with salicylic acid decreases the effect of chilling injury in maize (Zeamays L.) plants. Planta. 1999;208(2):175-80

25. Mora-Herrera ME, Lopez-Delgado H, Castillo-Morales A, Foyer CH. Salicylic acid and $\mathrm{H}_{2} \mathrm{O}_{2}$ function by independent pathways in the induction of freezing tolerance in potato. Physiol Plant. 2005;125(4):430-40.

26. Kusumi K, Yaeno T, Kojo K, Hirayama M, Hirokawa D. The role of salicylic acid in the glutathione-mediated protection against photooxidative in rice. Physiol Plant. 2006;128:651-61.

27. Stevens J, Senaratna T, Sivasithamparam K. Salicylic acid induces salinity tolerance in tomato (Lycopersicon esculentum cv. Roma): associated changes in gas exchange, water relations and membrane stabilization. Plant Growth Regul. 2006;49(1):77-83.

28. Gunes A, Inal A, Alpaslan M, Eraslan F, Bagci E G, Cicek N. Salicylic acid induced changes on some physiological parameters symptomatic for oxidative stress and mineral nutrition in maize (Zeamays L.) grown under salinity. J Plant Physiol. 2007;164(6):728-36.

29. Eraslan F Inal A, Gunes A Alpaslan M. Impact of exogenous salicylic acid on the growth, antioxidant activity and physiology of carrot plants subjected to combined salinity and boron toxicity. Sci Hortic. 2007;113(2):120-8.

30. Arfan M, Athar HR, Ashraf M. Does exogenous application of salicylic acid through the rooting medium modulate growth and photosynthetic capacity in two differently adapted spring wheat cultivars under salt stress?. J Plant
Physiol. 2007;164(6):685-94

31. Quiroz-Figueroa F, Mendez-Zeel M. Picomolar concentration of salicylates induce cellular growth and enhance somatic embryogenesis in Coffea arabica tissue culture. Plant Cell Rep. 2001;20(8):679-89.

32. Luo JP, Jiang ST, Pan LJ. Enhanced somatic embryogenesis by salicylic acid of Astragalus adsurgens Pall.: relationship with $\mathrm{H}_{2} \mathrm{O}_{2}$ production and $\mathrm{H}_{2} \mathrm{O}_{2}$-metabolizing enzyme activities. Plant Sci. 2001;161(1):125-32.

33. Hao L, Zhou L, Xu X, Cao J, XiT. The role of salicylic acid and carrot embryogenic callus extracts in somatic embryogenesis of naked oat (Avena nuda). Plant Cell, Tissue Organ Cult. 2006:85(1):109-13.

34. Hussein K, Sahadevan KK, Salim N. Bioaccumulation and release of mercury in Vigna mungo (L.) hepper seedlings. J Stress Phys Biochem. 2010;6(3):56-63.

35. Kasparova M, Siatka T, and Dusek J. Production of isoflavonoids in the Trifolium pratense L. suspension culture. Ceska Slov Farm. 2009;58(2):66-69.

36. Kasparova M, Siatka T, Dusek J. Biotic elicitation of the Trifolium pratense L. suspension culture, Ceska a Slovenska Farmacie, 2008;57(3):107-10.

37. Lolkema PC, 1985. Copper resistance in higher plants. Ph.D. Thesis, Free University Press.

38. Ghaemi MA, Sarrafi, Alibert G. The effects of silver nitrate, colchicine, cupric sulfate and genotype on the production of embryoids from anthers of tetraploid wheat (Triticum turgidum). Plant Cell Tiss Org Cult. 1994;36(3):355-9 DOI:10.1007/BF00046093.

39. Dahleen, LS. Improved plant regeneration from barley callus cultures by increased copper levels. Plant Cell Tiss. Org. Cult, 1995:43(3):267-9. DOI:10.1007/F00039954.

40. Vinod K, Awasthi G, Chauhan PK. Cu and Zn tolerance and responses of the Biochemical and Physiochemical system of Wheat. J Stress Physiol Biochem. 2012:8(3):203-13.

Harborne J B., 1998. Methods of extraction and isolation.In; Phytochemical Methods. London, UK; Champman and Hall, 60-4

M. Kasparova, T. Siatka, and J. Dusek., 2009. "Production of isoflavonoids in the Trifolium pratense L. suspension culture," Ceska a Slovenska Farmacie, vol. 58 , no. 2, pp. 67-70.

Omori T., 1996. Involvement of Jasmonic acid in elicitor induced phytoalexin production in suspension cultured rice cells.Plant Physiology: $110387-392$

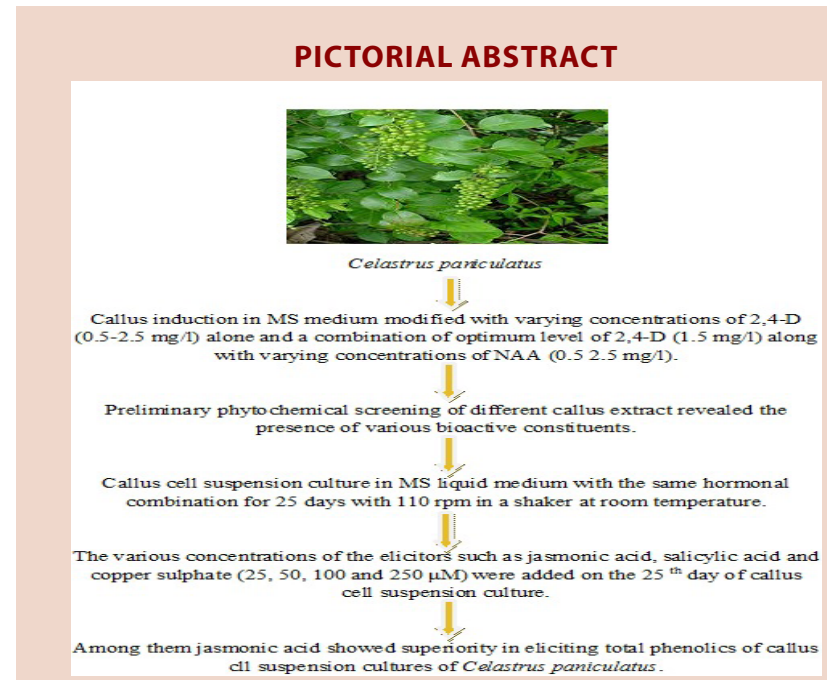

\section{SUMMARY}

- Celastrus paniculatus is an endangered medicinal plants in India.

- The optimum level of 2,4-D (1.5 mg/l) along with the combination of $1.0 \mathrm{mg} / \mathrm{lof}$ NAA resulted maximum callus response from the midrib of the leaf explants.

- The preliminary phyto $\neg$ chemical screening of the different callus extracts of celastrus paniculatus contained many bioactive constituents which includes reducing sugars, anthraquinones, phenols, flavanoids, alkaloids, steroids, terpenoids, phlobotannins, aldehydes / ketones, glycosides, saponins and tannins.

- The present study revealed that jasmonic acid is the most effective in eliciting in total phenolic production of callus cell suspension cultures of Celastrus paniculatus.

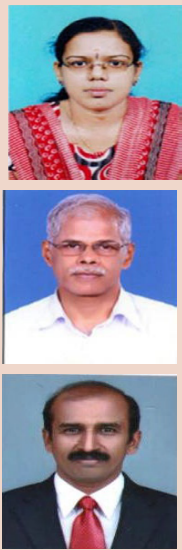

\section{ABOUT AUTHORS}

Anusha T S: Is a doctoral student at University of Calicut, Department of Biotechnology. She is a post graduate in Biotechnology and a M.Phil holder in the same subject. Her doctoral research focused on comparative antioxidant, anti-inflammatory and anti-proliferative activity of both micropropagated and field grown plant of Celastrus paniculatus.

Prof. Joseph M V (Retired): Is specialized in Microbiology and immunology, plant secondary metabolites/ immuno-modulatory compounds. He received his post-doctoral fellowship from Washington University, St. Louis USA (1986-1990) and having more than thirty years of experience in teaching and research.

Prof. Elyas K K: Is a Doctoral holder in Immunology, from Medical College, Trissur, Calicut University, in 2007. Also an M.Tech holder in Biotechnology, from Anna University, Madras, 1991 and received his post-graduation in Biotechnology from Aligarh Muslim University UP, 1989. 